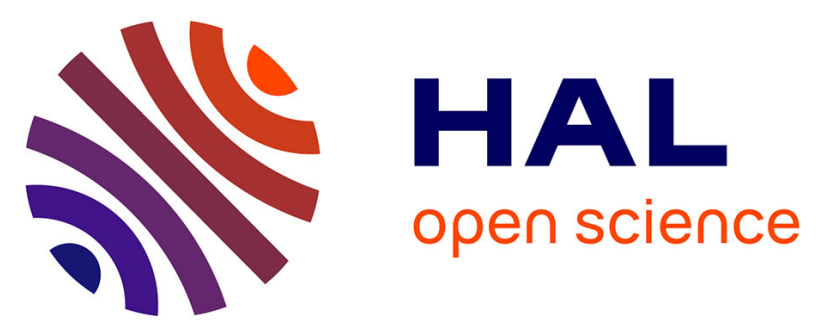

\title{
Contrasted morphosedimentary activity of the lower Kert River (northeastern Morocco) during the Late Pleistocene and the Holocene. Possible impact of bioclimatic variations and human action
}

Mohammed El Amrani, Jean-Jacques Macaire, Hamid Zarki, Jean-Gabriel Bréhéret, Michel Fontugne

\section{To cite this version:}

Mohammed El Amrani, Jean-Jacques Macaire, Hamid Zarki, Jean-Gabriel Bréhéret, Michel Fontugne. Contrasted morphosedimentary activity of the lower Kert River (northeastern Morocco) during the Late Pleistocene and the Holocene. Possible impact of bioclimatic variations and human action. Comptes Rendus Géoscience, 2008, 340, pp.533-542. 10.1016/j.crte.2008.05.004 • insu-00310976

\section{HAL Id: insu-00310976 \\ https://hal-insu.archives-ouvertes.fr/insu-00310976}

Submitted on 12 Aug 2008

HAL is a multi-disciplinary open access archive for the deposit and dissemination of scientific research documents, whether they are published or not. The documents may come from teaching and research institutions in France or abroad, or from public or private research centers.
L'archive ouverte pluridisciplinaire HAL, est destinée au dépôt et à la diffusion de documents scientifiques de niveau recherche, publiés ou non, émanant des établissements d'enseignement et de recherche français ou étrangers, des laboratoires publics ou privés. 


\title{
Contrasted morphosedimentary activity of the lower Kert River (northeastern Morocco) during the Late Pleistocene and the Holocene. Possible impact of bioclimatic variations and human action
}

\author{
Mohamed El Amrani a , Jean-Jacques Macaire ${ }^{\mathrm{a}}$, Hamid Zarki ${ }^{\mathrm{b}}$, Jean-Gabriel Bréhéret ${ }^{\mathrm{a}}$ \\ and Michel Fontugne ${ }^{c}$ \\ ${ }^{a}$ Université François-Rabelais de Tours, Université d'Orléans, CNRS/INSU, Institut des \\ Sciences de la Terre d'Orléans, UMR CNRS 6113, faculté des sciences et techniques, parc de \\ Grandmont, 37200 Tours, France \\ ${ }^{\mathrm{b}}$ Laboratoire de géologie, faculté des sciences de dhar Mahraz, BP 1796, Fès-Atlas, Maroc \\ ${ }^{c}$ UMR CNRS CEA 1572, laboratoire des sciences du climat et de l'environnement, parc du \\ CNRS, Bat. 12, 91198 Gif-sur-Yvette cedex, France
}

\begin{abstract}
From field observations in the lower Kert valley and 16 radiocarbon dating measurements, six alluvial units (UF1 to UF6) deposited since about 30,000 years BP have been identified, comprising 18 lithofacies and separated by six incision stages resulting in three alluvial terraces (T1 to T3). While the Late Pleistocene is mainly marked by sedimentary accretion (UF1 forming part of T1), the Holocene is marked by the alternation of major incision (I2, I3 and I4) and accretion (UF2 and UF3) stages, with roughly similar height ranges, between the current river level and polyphased T1 surface. During the Lower and Middle Holocene, this complex morphosedimentary evolution could have been the result of contrasted bioclimatic trends that did not appear during the Late Pleistocene. Human activities modified the earth surface conditions, intermittently during the Middle Holocene, and during the Upper Holocene, inducing new responses from the fluvial geosystem to the environment.
\end{abstract}

\section{Résumé}

Activité morpho-sédimentaire contrastée de l’oued Kert dans son cours inférieur (Maroc nord-oriental) pendant le Pléistocène récent et l'Holocène. Impact possible des variations bioclimatiques sur les activités humaines. Les observations de terrain dans la basse vallée du Kert et 16 datations ${ }^{14} \mathrm{C}$ ont permis d'identifier six unités alluviales (UF1 à UF6) comprenant 18 lithofaciès, mises en place depuis environ 30000 ans et séparées par six phases d'incision (I1 à I6) ayant engendré trois terrasses alluviales (T1 à T3). Tandis que le Pléistocène récent est surtout marqué par l'accrétion sédimentaire (UF1 formant T1 pro parte), l'Holocène est caractérisé par l'alternance de phases majeures d'incision (I2, I3 et I4) et d'accrétion sédimentaire (UF2, UF3) développées entre la surface de T1, polyphasée, et le lit actuel de l'oued. Cette évolution morphosédimentaire complexe résulterait, pour l'Holocène inférieur et moyen, de tendances bioclimatiques contrastées, non réalisées au Pléistocène récent. À l'Holocène moyen, temporairement, et surtout à l'Holocène supérieur, les activités humaines ont profondément modifié le fonctionnement du géosystème sédimentaire.

Keywords: Fluvial sedimentation; Alluvial terraces; Late Pleistocene; Holocene; Morocco; Climate; Human impact 
Mots clés: Sédimentation fluviatile; Terrasses alluviales; Pléistocène récent; Holocène; Maroc; Climat; Anthropisation

\section{Version française abrégée}

Dans les régions méditerranéennes, les systèmes fluviaux ont été particulièrement réactifs aux variations des paramètres environnementaux du Quaternaire : tectonique, climat, et activités humaines précoces dans ces régions [7], [22], [23] and [42]. Les phases d'alluvionnement ou d'incision sont généralement interprétées en termes climatiques : l'accrétion sédimentaire est attribuée à des périodes, soit d'aridité [15] and [21], soit d'humidité [1] and [41], soit de transition aride-humide [40]. L'impact anthropique n'est évoqué que pour les deux ou trois derniers millénaires [1], [7] and [40]. Les observations lithologiques et morphologiques effectuées sur la basse vallée de l'oued Kert au Maroc nord-oriental, calées chronologiquement grâce à 16 datations ${ }^{14} \mathrm{C}$, ont montré la succession d'importantes phases d'incision et de sédimentation au cours du Pléistocène récent et de l'Holocène. Cette note vise à décrire ces fluctuations et à en interpréter l'origine.

L'oued Kert se trouve à l'ouest de Nador (Fig. 1). Son bassin versant $\left(2873 \mathrm{~km}^{2}\right)$ s'élève jusqu'à $1800 \mathrm{~m}$ d'altitude dans le Rif, en domaine surtout sédimentaire. Le climat est méditerranéen semi-aride, et la végétation très clairsemée [36]. Cette étude porte sur les 30 derniers kilomètres de l'oued. Son cours sinueux suit des accidents structuraux majeurs (Fig. 1). Plusieurs niveaux de terrasses alluviales quaternaires ont été décrits dont une terrasse majeure attribuée à l'Holocène [5] and [6]. De grandes coupes dégagées par l'érosion ont pu y être étudiées. Six unités alluviales, notées UF1 à UF6, de la plus ancienne à la plus récente, comprenant 18 lithofaciès, et trois unités colluviales (UC1 à UC3) intercalées entre les unités alluviales, ont été identifiées (Fig. 2). Elles sont séparées par six phases d'incision (I1 à I6). Cette évolution a engendré trois terrasses alluviales : T1 est la terrasse majeure, haute de $20 \mathrm{~m}$ au-dessus du lit de l'oued en amont et $0 \mathrm{~m}$ en aval; T2 et T3 sont situées en contrebas. Les datations ${ }^{14} \mathrm{C}$ s'échelonnent entre $28375 \pm 450$ et $1370 \pm 40$ ans ${ }^{14} \mathrm{C}$ BP (Tableau 1).

$\mathrm{Au}$ Pléistocène récent, l'accrétion de l'UF1, commencée un peu avant $28375 \pm 450$ ans ${ }^{14} \mathrm{C}$ $\mathrm{BP}$ et terminée un peu après $12300 \pm 155$ ans ${ }^{14} \mathrm{C} \mathrm{BP}$, s'est effectuée en deux phases (UF1a et UF1b), séparées par une période de stabilité ou de légère incision (I1), non datée, en contexte de forte régression marine [16] and [27]. La sédimentation dominante indique une forte production sédimentaire, sans doute favorisée par la couverture végétale généralement herbacée sous climat frais et humide [8] and [20]. Le bas niveau marin ne paraît pas avoir réduit la capacité de stockage sédimentaire dans la basse vallée, la sédimentation ayant peutêtre été favorisée par la subsidence (tronçons I et II), comme suggéré par [5]. Les faciès sédimentaires traduisent deux épisodes à hydrologie régulière, probablement humides, l'un dans la partie inférieure d'UF1a, confirmé par les données palynologiques [6], et l'autre à la partie supérieure d'UF1b. Ils encadrent des faciès indiquant des écoulements plus irréguliers dans UF1a et UF1b, parfois de forte énergie, avec des épisodes prolongés d'arrêt de sédimentation (formation de croûtes calcaires). Ces caractères hydrologiques paraissent en accord avec l'évolution climatique - phase plus humide vers 30000 ans, phase plus sèche après 20000 ans ${ }^{14} \mathrm{C} \mathrm{BP}$, augmentation de l'humidité vers 14000 ans ${ }^{14} \mathrm{C} \mathrm{BP}$ - reconnue en Méditerranée occidentale [1], [8], [17], [20], [31] and [32]. 
La phase d'incision majeure I2, développée au Pléistocène récent après 12300 ans ${ }^{14} \mathrm{C} \mathrm{BP}$ et à l'Holocène inférieur avant 7935 ans ${ }^{14} \mathrm{C} \mathrm{BP}$ en contexte de forte remontée eustatique [11] and [27], est générale au Maroc [5], [30], [37], [38] and [41]. Le couvert végétal steppique développé sous climat aride [4], [8], [20] and [31] et plus chaud après 10000 ans ${ }^{14} \mathrm{C}$ BP [12] ayant été favorable à la production sédimentaire, seule une hydrologie irrégulière et temporairement énergique peut expliquer l'évacuation de la matière vers la mer et l'incision profonde dans les alluvions UF1.

Pendant l'Holocène moyen, le bilan sédimentaire montre de forts contrastes : accrétion importante de l'UF2 entre au moins 7935 et 6220 ans ${ }^{14} \mathrm{C}$ BP, suivie de l'incision I3, rapide, qui a déstocké un très fort volume de matériaux (jusqu'à $15 \mathrm{~m}$ d'épaisseur et sur presque toute la largeur de la terrasse T1) entre 6220 et 5300 ans ${ }^{14} \mathrm{C}$ BP. Cette évolution ne peut être expliquée par les variations eustatiques faibles [16] and [26] ou par des mouvements tectoniques. Le dépôt de l'UF2 paraît lié à un contexte bioclimatique humide et frais [4], [8], [12], [14] and [38], voisin de ceux du Pléistocène récent, avec production sédimentaire marquée et une hydrologie régulière montrée par les faciès rythmés. Cependant, le faciès supérieur de l'UF2, omniprésent plus tard dans l'UF3, indique des apports plus grossiers et irréguliers, peu en accord avec l'augmentation de l'humidité et de la densité du couvert forestier à cette époque [4], [8] and [10]. Il pourrait traduire une dégradation temporaire locale de la végétation par des activités humaines précoces : la forte densité de foyers anthropiques dans UF2, notée ailleurs au Maroc nord-oriental à cette époque [6], et le début de l'agropastoralisme dans le Rif avant 6000 ans ${ }^{14} \mathrm{C} \mathrm{BP}$ [3] rendent plausible cette hypothèse. L'incision ultérieure $\mathrm{I} 3$ est en accord avec le contexte bioclimatique, devenu très humide et plus chaud dans la seconde partie de l'Holocène moyen [4], [8], [12], [14] and [38], qui a favorisé le développement de la forêt de chênes et donc la réduction de la production solide.

À l'Holocène supérieur, la forte accrétion de l'UF3 jusqu'au niveau de la terrasse T1 entre $5285 \pm 45$ et $1370 \pm 40$ ans ${ }^{14} \mathrm{C} \mathrm{BP}$ correspond à une phase de production sédimentaire majeure : en effet, si le flux solide avait été constant, la tectonique et les variations eustatiques ne peuvent expliquer une telle augmentation du stockage dans la basse vallée. Les faciès inférieurs de l'UF3 traduisent bien les environnements humides antérieurs à 4000 ans ${ }^{14} \mathrm{C} \mathrm{BP}$, mais les faciès alluviaux supérieurs et l'abondance des apports colluviaux, parfois riches en cendres, indiquent des apports très abondants, irréguliers, accompagnés d'incendies fréquents. Ceci est en accord avec l'éclaircissement du couvert végétal pouvant résulter de l'aridification et du réchauffement du climat [4], [12], [17] and [18]. Mais la désertification végétale peut aussi être due aux activités humaines, dont les effets ont été largement reconnus au Maroc après 5000 ans ${ }^{14} \mathrm{C} \mathrm{BP}$ [2], [19] and [28]. Dans la basse vallée du Kert, les nombreux foyers en place dans les sédiments et l'abondance des cendres issues d'incendies sur les versants montrent une forte occupation humaine, surtout entre 4000 et 3000 ans ${ }^{14} \mathrm{C}$ BP. Ces éléments, et le fait que, lors des périodes antérieures, l'aridité induit l'incision, ici comme généralement au Maghreb [1], [39] and [41], conduisent à proposer que l'anthropisation du bassin a pu exacerber l'effet de l'aridité sur la végétation après 4000 ans ${ }^{14} \mathrm{C} B P$, peut-être aussi modifier l'hydrologie et produire une quantité exceptionnelle de matière ayant engorgé la basse vallée (stocks UF3). L'incision majeure polyphasée apparue après 1370 ans ${ }^{14} \mathrm{C}$ BP (phases I4, I5 et I6), en contexte bioclimatique toujours sub-aride et chaud, semble résulter d'un tarissement des apports solides malgré l'anthropisation croissante liée notamment à la conquête arabe [6] and [19] : l'exceptionnelle production sédimentaire à l'Holocène supérieur avant 1370 ans ${ }^{14} \mathrm{C}$ BP a pu épuiser l'essentiel de la matière facilement mobilisable sur les versants (sols, régolites) et les aménagements ont pu en stocker une part sur les versants. Les phases de dépôt UF4, UF5 et UF6 sont secondaires : UF4 (terrasse T2) paraît correspondre à un bref épisode 
de stationnement de l'oued au cours de l'incision ; UF5 (terrasse T3) et UF6 (dépôts actuels) marquent une forte augmentation à la fois de l'énergie de l'oued et des apports depuis les reliefs d'amont, qui pourraient traduire des fluctuations mineures du climat et/ou de l'impact des sociétés humaines.

\section{Introduction}

A considerable amount of information on palaeoenvironments can be obtained from fluvial sediment composition and distribution in valleys. In Mediterranean regions, fluvial systems are highly reactive to changes in environmental parameters: not only tectonics, which was often active during the Quaternary period [22] and [42], but also climate change, and of course human activity, which goes back to the earliest times in these regions [7] and [23].

In the Maghreb generally, the occurrence of Late Pleistocene deposits is rare, while several Holocene fluvial sedimentary units have been observed. Deposition periods were separated by incision periods in which terraces were formed with increasingly lower surfaces than the main terrace, which was formed of deposits during either the Late Pleistocene [1], [30] and [41], or more often the Lower or Middle Holocene [6], [37], [39] and [40], Late Pleistocene deposits being generally eroded during the erosion-dominated Holocene period. Holocene sediments sometimes form a series containing palaeosoils, indicating periods of morphological stability $[15]$.

Periods of river erosion or sedimentation are generally related to bioclimatic conditions: according to some authors, sedimentary accretion corresponds to periods of either aridity [15] and [21], humidity [1] and [41], or aridity-humidity transition [40]. Human impact on river activity has only be observed for the last two or three millennia [1], [7] and [40]: this impact was high when it was developed in synergy with bioclimatic conditions that were particularly favourable to erosion [7] and [13], or low when it was antagonistic to climate effects [15].

Lithological and morphological studies of the lower Kert River in northeastern Morocco and $16{ }^{14} \mathrm{C}$ dating measurements show alternating periods of depth incision and depth sediment accretion during the Late Pleistocene and the Holocene. This paper deals with these sedimentological and morphological data and interpretations.

\section{Kert River catchment}

The Kert River flows into the Mediterranean Sea $25 \mathrm{~km}$ west of the city of Nador $\left(35^{\circ} 11^{\prime} \mathrm{N}\right.$ and $2^{\circ} 56^{\prime} \mathrm{W}$ ) in northeastern Morocco (Fig. 1). Its catchment $\left(2873 \mathrm{~km}^{2}\right)$ comprises mountains (elevation up to $1800 \mathrm{~m}$ in the Rif) made up of a complex mosaic of Palaeozoic to Miocene micaschists, schists, sandstones, marls and limestones, and Miocene and Quaternary volcanic rocks, separated by broad depressions filled with Mio-Plio-Quaternary sediments. This area is marked by an intense seismic activity [9]. The present-day climate is semi-arid Mediterranean (mean annual precipitation $290 \mathrm{~mm}$, mean temperature $17.5^{\circ} \mathrm{C}$ ), with irregular rainfall. Vegetation is very scarce: forest covers $4 \%$ of the catchment surface in the highlands, and elsewhere degraded forest (matorral) or Alfa and Artemisia steppe-like vegetation due to overpasturing predominates [36].

This study concerns the final 30-km stretch of the Kert River before it reaches the Mediterranean Sea; the elevation decreases from 150 to $0 \mathrm{~m}$, and the mean water discharge is $4 \mathrm{~m}^{3} \mathrm{~s}^{-1}$ (but can be as high as $216 \mathrm{~m}^{3} \mathrm{~s}^{-1}$ ). The valley is sinuous and formed by faults (Fig. 
1). Several Quaternary alluvial terraces have been described [5] and [6]. The main terrace, which is omnipresent and up to $1200 \mathrm{~m}$ wide, lies about $20 \mathrm{~m}$ above the present Kert channel in stretches I and II and has been dated from the Holocene by Barathon [5] and Barathon et al. [6]. Recent alluvium erosion has generated extended sections, up to $10 \mathrm{~m}$ thick, and sometimes uninterrupted for several kilometres on both sides of the river.

\section{Composition, age and distribution of sedimentary units}

Six alluvial units, named UF1 to UF6 from the earliest to the youngest, characterized by 18 lithological facies, and three colluvial units (UC1 to UC3), have been identified along the final $30 \mathrm{~km}$ of the Kert (Fig. 2). These units form three alluvial terraces: T1 is the main terrace, $20 \mathrm{~m}$ above the present Kert channel in the upstream stretches and $0 \mathrm{~m}$ in the downstream stretch; T2 and T3 terraces are lower. ${ }^{14} \mathrm{C}$ dating measurements, expressed according to conventional ages $\left({ }^{14} \mathrm{C}\right.$ a BP $)$, range from $28,375 \pm 450$ to $1370 \pm 40{ }^{14} \mathrm{C}$ a $\mathrm{BP}$ (Table 1).

Unit UF1 (up to $20 \mathrm{~m}$ thick) is widespread in river stretches I, II and III (Fig. 2 and Fig. 3). It extends from the present river level up to the surface of T1, and comprises two sub-units, UF1a and UF1b, composed from base to top of the following bodies:

- unit UF1a (up to $12 \mathrm{~m}$ thick): blackish clayey silts containing woody fragment dated $28,375 \pm 450{ }^{14} \mathrm{C}$ a BP, conglomerate, alternating beds of in situ travertine and sand formed of travertine clasts, thick series ( 3 to $8 \mathrm{~m}$ ) of rhythmic yellowish sandy beds and greyish silty beds, pebbles in a sandy matrix, pinkish silts with pebbles, yellowish sands with pebbles and greyish silts. Syn-sedimentary faults with normal shift and a throw of several decimetres have been observed in some bodies (blackish clayey silts, travertine and yellowish sands with pebbles);

- unit UF1b (up to $10 \mathrm{~m}$ thick): conglomerates, yellowish sands with pebbles and calcretes, thick series (up to $6 \mathrm{~m}$ ) of rhythmic pinkish sandy beds and greyish silty beds containing one firesite located two metres under the T1 surface, with pieces of charcoal dated 12,300 \pm 155

${ }^{14} \mathrm{C}$ a BP; there is a deep, reddish-coloured soil at the top of UF1, which is either buried (palaeosoil) or crops out.

Both UF1a and UF1b can be observed in the middle stretch of the valley (section D, Fig. 2). In the upstream stretch, only UF1a occurs below UF3 (sections A, B and C, Fig. 2), whereas downstream, only UF1b is observed below UF3 (sections H and I, Fig. 2).

UF2 (up to $10 \mathrm{~m}$ thick) was observed in stretches I and II (sections B, D and E, Fig. 2), overlying eroded UF1 deposits; its base lies at the present river level and its eroded top does not form a terrace. UF2 is composed, from base to top, of pebbles in a sandy matrix, series of rhythmic yellowish sandy beds and greyish silty beds, and unrhythmic beds of beige silts and sands. Three dates obtained in this unit range from $7935 \pm 45$ to $6220 \pm 70{ }^{14} \mathrm{C}$ a BP.

UF3 (up to $20 \mathrm{~m}$ thick) was observed in the four defined valley stretches (Fig. 2 and Fig. 3). Its base either crops out at the present river level, or lies on UF1 or UF2, and its top often forms the T1 terrace, at a level similar to that of the UF1 top in stretches I and II. It generally comprises, from base to top: darkish organic silts (sections I and J, Fig. 2) or pebbles in a sandy matrix, a main body of unrhythmic beige silty and sandy beds, and series of rhythmic pinkish sandy and greyish silty beds. This last facies shows syn-sedimentary deformations, 
interpreted as seismite structures [25] and [33]. The beige silty sandy facies contains widespread layers of greyish silts, enriched with wood ash. UF3 also contains sandy silty colluvium or mud flow deposits close to the valley sides, and, locally, sands formed of travertine clasts. Numerous anthropogenic firesites have been given 11 dates ranging from $5285 \pm 45$ to $1370 \pm 40{ }^{14} \mathrm{C}$ a BP, most of them between 4000 and $3000{ }^{14} \mathrm{C}$ a BP (Table 1).

UF4 is not very extensive, and $2 \mathrm{~m}$ thick at the most. It overlies eroded UF3 deposits and forms the T2 terrace 12-14 $\mathrm{m}$ above the river (sections A, D and H, Fig. 2). UF4, which has not been dated, is composed of beige silty sandy beds, containing pebbles of clayey silty material, overlain by sands made up of travertine clasts.

UF5 makes up the T3 terrace, very marked in the landscape $5 \mathrm{~m}$ above the river (sections $\mathrm{E}, \mathrm{F}$ and H, Fig. 2 and Fig. 3). UF5 deposits, $4 \mathrm{~m}$ thick at the most, overlie eroded UF1, UF2 or UF3 deposits. They comprise alternations of pebbles with sandy matrix beds and beige silt and sand beds, with predominant cross-bedding. UF5 could not be dated.

UF6 corresponds to the present-day Kert deposits, composed of sands, gravels and pebbles, sometimes with metric clasts, deposited in a braided fluvial channel system. This unit can be several metres thick, but bed-rock sometimes crops out at the river bed bottom.

$\mathrm{UC} 1, \mathrm{UC} 2$ and UC3 colluvial units, interbedded between alluvial units, are 1 to $3 \mathrm{~m}$ thick and made up of unbedded sandy silts containing scattered gravels and pebbles. They have not been dated. UC1, reddish in colour, overlies UF1 (sections A, C and I, Fig. 2 and Fig. 3) and shows a greyish palaeosoil containing calcareous concretions. Locally (stretch III), a deep torrential unit (up to $10 \mathrm{~m}$ thick), made up of blocks and pebbles, fills a gully cut into T1 terrace down to the present river level (section I, Fig. 2). UC2, greyish and with poorly developed palaeosoil, overlies UF2 and is overlain by UF3 (sections B and E, Fig. 2). UC3 overlies UF3 close to the valley sides (sections B, D, E and F, Fig. 2).

\section{Interpretation}

\subsection{Chronology and intensity of incision and sedimentary accretion events}

The Late Pleistocene from about 30,000 years was mainly marked by sedimentary accretion. After a period of incision (indexed I0, Fig. 4) down to the present river level, UF1 sedimentary accretion (up to $20 \mathrm{~m}$ thick in stretch II) began a little before $28,375 \pm 450{ }^{14} \mathrm{C}$ a $\mathrm{BP}$ and stopped soon after $12,300 \pm 155{ }^{14} \mathrm{C}$ a BP on section $\mathrm{D}$, with probably a period of stability or weak incision (I1), not dated, between UF1a and UF1b, as shown by conglomerates filling the channel cut into underlying sediments and yellowish sands with pebbles and calcretes. The dating of $28,375{ }^{14} \mathrm{C}$ a BP obtained in blackish clayey silts confirms the date obtained by [6] $\left(32,138 \pm 1334{ }^{14} \mathrm{C}\right.$ a BP), but considered as inaccurate by these authors. In stretch II, UF1 makes up the T1 terrace pro parte (Fig. 3). The upper subunit UF1b is eroded in stretch I, but crops out widely downstream (stretch III): its top forms a planar palaeosurface with a palaeosoil, preserved over a long distance, whose height above the present river decreases sharply downstream. The UF1 palaeosurface is about $30-35 \mathrm{~m}$ under the present shoreline.

The Holocene is marked by alternations of several periods of strong incision and sedimentary accretion (Fig. 4). The major incision I2, shown by an elevation of the UF2 base and UC1 colluvium on UF1, was initiated at the end of the Pleistocene (after $12,300{ }^{14} \mathrm{C}$ a BP) and/or 
during the Lower Holocene (before $7935 \pm 45{ }^{14} \mathrm{C}$ a BP): the incision is $20 \mathrm{~m}$ deep in stretches I and II. Later, UF2 accretion (up to $10 \mathrm{~m}$ ) developed during the first part of the Middle Holocene, between at least $7935 \pm 45$ and $6220 \pm 70{ }^{14} \mathrm{C}$ a BP. These deposits overlie eroded UF1 and do not form a terrace: deep erosion of upper UF2 sediments suggests that top-unit elevation was close to the T1 surface. The next I3 incision period developed during the second part of the Middle Holocene after $6220 \pm 70$ and before $5285 \pm 45{ }^{14} \mathrm{C}$ a BP. Incision was very extensive, $10-15 \mathrm{~m}$ deep and very wide, mainly in valley stretches III and IV. UF3, deposited during the Upper Holocene between $5285 \pm 45$ and $1370 \pm 40{ }^{14} \mathrm{C}$ a BP, is the most voluminous: deposits up to $19 \mathrm{~m}$ thick form the main part of T1. In stretch II, the height of the top of UF3 is similar to that of UF1, which gives the polygenic characteristic of the T1 terrace (Fig. 4). Elsewhere, UF3 covers UF1 or UF2, especially the palaeosoil of UF1b in stretch III. T1 elevation, $20 \mathrm{~m}$ above the present river in stretches I and II, decreases downstream to the present-day sea level. The Upper Holocene, since $1370{ }^{14} \mathrm{C}$ a $\mathrm{BP}$, is mainly marked by incision (20 m upstream and $0 \mathrm{~m}$ downstream): three stages of incision (I4, I5 and I6) separated by stages of low sedimentary accretion (UF4, UF5 and UF6) induced lower T2 and $\mathrm{T} 3$ terraces.

This pattern of valley evolution differs from that of [6], mainly because these authors did not identify Pleistocene deposits. Moreover, while several morphosedimentary Holocene stages have been identified in Morocco, they are generally fewer and of lower intensity than in the Kert valley [21], [37], [39] and [40].

\subsection{Origin of sediment budget changes during the Late Pleistocene and the Holocene}

In the lower Kert valley, while the final Pleistocene sediment budget is mainly marked by accretion, the Holocene is marked by strong sediment-budget changes. The budget, either positive or negative, is the result of a solid sediment yield value in the catchment and the sediment-retention capacity of the lower Kert valley, which depended on environmental changes during the Holocene, such as tectonics, climate, vegetation, sea level and human activities [24].

UF1 accretion during the Late Pleistocene after 30,000 years BP developed during periods of low sea level, as shown by the sediment palaeosurface elevation, with no obvious major change in river activity. During that glacial period, the fact that deposition predominated for about 20,000 years while the sea level was very low [16] and [27], as already observed in Morocco [39] and [41], shows that: (1) sediment yield was high, possibly encouraged by continuous grass-dominated vegetation due to a mainly cool evolution cannot be explained by low sea level did not decrease sediment-storage capacity in the lower valley; sediment storage was possibly encouraged by local subsidence (particularly in stretches I and II), as suggested by [5]. Sediment facies indicate two periods of regular hydrology and a more humid climate: blackish clayey silts, travertine, sands formed of travertine clasts, and rhythmic yellowish sandy and greyish silty beds in the lower part of UF1a, and rhythmic pinkish sandy and greyish silty beds in the upper part of UF 1b. This climatic trend is confirmed by pollen data in blackish clayey silts [6]. These periods are separated by facies showing more irregular flows (pebbles in a sandy matrix, pinkish silts with pebbles, yellowish sands with pebbles and greyish silts in UF1a, and conglomerates and yellowish sands with pebbles and calcretes in UF1b), sometimes of high energy, which could have eroded earlier deposits (stage I1 with little incision), with long periods without sedimentation marked by calcrete formation. This hydrological pattern is in accordance with climate changes - more humid at about 30,000 
years BP, more arid after $20,000{ }^{14} \mathrm{C}$ a BP, increased humidity at about $14,000{ }^{14} \mathrm{C}$ a BP shown by lake level [17], vegetation [8] and [20], atmospheric circulation [31] and [32] and fluvial sedimentation [1] in Mediterranean regions.

Main incision stage I2, developed after $12,300{ }^{14} \mathrm{C}$ a BP and before $7935{ }^{14} \mathrm{C}$ a BP during a period of rising sea level [11] and [27], has frequently been described in Morocco [5], [30], [37], [38] and [41]. It corresponds to an arid climate period at the end of the Pleistocene and during the Lower Holocene [4], [8], [20] and [31], becoming warmer after $10,000{ }^{14} \mathrm{C}$ a BP [12]. As steppe vegetation was favourable to sediment yield at that time, only irregular and sometimes high-energy river flows can explain how solid matter was carried down to the sea and deep incisions in UF1 sediments developed.

During the Middle Holocene from $8500{ }^{14} \mathrm{C}$ a BP, climate humidity first increased while the temperature decreased, then from 6500 to $4000{ }^{14} \mathrm{C}$ a BP humidity continued to rise and the temperature also increased: this has been referred to as the 'climatic optimum'. After that, aridity developed up to the present day [4], [8], [12], [14] and [38]. During this period, the sediment budget varied greatly: high sediment accretion developed from at least 7935 to 6220 ${ }^{14} \mathrm{C}$ a BP, then $\mathrm{I} 3$ incision occurred rapidly between 6220 and $5300{ }^{14} \mathrm{C}$ a BP, reworking a vast volume of material (15 $\mathrm{m}$ high for a large part of T1 extension). This contrasted evolution cannot be explained either by sea level variation, which was low during the Middle Holocene [16] and [26], or by tectonics. UF2 deposition seems to be related to a humid and cool climate, similar to the Late Pleistocene, which could have induced significant sediment yield and regular hydrology, as shown by rhythmic yellowish sandy beds and greyish silty beds observed in both UF2 and UF1. Nevertheless, upper UF2 facies of unrhythmic beige silty and sandy beds, which are more predominant in UF3, show discharges of coarser material as a consequence of irregular hydrology, which is inconsistent with increased humidity and forest cover at that time [4], [8] and [10]. This type of facies could indicate temporary clearing of vegetation in the catchment due to either climate change (weak aridification?) or early human activities. This hypothesis is supported by an abundance of anthropogenic firesites in UF2, found extensively elsewhere in northeastern Morocco at that time [6], and the beginning of crop cultivation and pasturing in the Rif Mountains from as early as $6000{ }^{14} \mathrm{C}$ a BP [3]. A further $\mathrm{I} 3$ incision stage is consistent with a warmer and very humid climate during the second part of the Middle Holocene, which favoured oak-forest development and thus decreased sediment yield.

During the Upper Holocene, from about $4000{ }^{14} \mathrm{C}$ a BP, the climate was marked by high aridification [4], [17] and [18] and was warmer [12]. Strong UF3 accretion up to the T1 level between $5285 \pm 45$ and $1370 \pm 40{ }^{14} \mathrm{C}$ a BP corresponds to periods of major sediment-yield increase, because this increased sediment storage in the lower Kert valley cannot be explained by tectonics or sea-level change. Lower UF3 facies (darkish organic silts and travertines) are consistent with a humid climate prior to $4000{ }^{14} \mathrm{C}$ a BP, but the widespread development of further unrhythmic beige silty and sandy beds, sometimes rich in wood ash and with abundant interbedded colluvial deposits, indicates the discharge of large quantities of solid material from the valley sides, fostered by irregular hydrology and frequent vegetation fires. Increased slope erosion and sediment yield, related to less protection of the soil by vegetation, could be due to a more arid climate. Desertification could also be due to vegetation clearance by human action, often seen in Morocco since about $5000{ }^{14} \mathrm{C}$ a BP [2], [19] and [28]. Abundant in situ firesites and dispersed wood ash in UF3 sediments indicate extensive human activities in the lower Kert valley, especially between 4000 and $3000{ }^{14} \mathrm{C}$ a BP. Previous arid periods are characterized by incision in the river stretches studied, as it is frequently the case in the 
Maghreb [1], [39] and [41]. From these observations, it can be concluded that human activities added to aridity affect vegetation, and probably also hydrology, after $4000{ }^{14} \mathrm{C}$ a BP. These environmental changes probably induced such a high sediment yield in the catchment that the Kert River could not discharge its whole sediment load downstream to the sea, storing a great part of it as UF3 deposits. Major cumulated incision developed in three stages (I4, I5 and I6) after $1370{ }^{14} \mathrm{C}$ a BP, without significant change in the warm, arid climate, which seems to indicate a sharp decrease in sediment yield, while human activities increased, particularly following the Arabian migration [6] and [9]. It is possible that a very high sediment yield during the Upper Holocene before $1370{ }^{14} \mathrm{C}$ a BP used up the source of material suitable for erosion (soils, regolites), or that eroded material was partly stored on slopes due to human activities. During this incision-dominated period, UF4, UF5 and UF6 deposition stages are slightly marked. UF4 sediments forming sparse T2 terrace seem to have been deposited during a brief period without incision. UF5 deposits, forming T3, and UF6 deposits show a high increase in river-water energy (predominance of sands, gravels and pebbles); they are mainly composed of coarse material discharged from upstream mountains, possibly indicating slight changes of climate or human action.

\section{Conclusion}

While the Late Pleistocene after 30,000 yrs BP, mainly cool and humid, but sometimes more arid, is mainly marked in the lower Kert valley by sedimentary accretion (UF1) forming part of the major T1 terrace, the Holocene period is marked by the alternation of three incision stages (I2, I3 and I4) and two accretion stages (UF2, UF3) with roughly similar height ranges, between the present-day river level and the polygenic surface of the T1 terrace. During the Lower and Middle Holocene, this highly contrasted morphosedimentary evolution seems to be due to bioclimatic trends that did not appear during the Late Pleistocene: UF2 sedimentary accretion at the beginning of the Middle Holocene seems to have been induced by climate cooling and humidity similar to that of the normal Late Pleistocene environment, while I2 and I3 incision stages correspond to a warmer climate, respectively extremely arid and extremely humid. During the Upper Holocene, the continuously warm and arid climate did not have the same effect on the fluvial sedimentary system as before, due to the emergence of more contrasted morphosedimentary Holocene events: UF3 accretion and I4 to I6 incisions. Human activities and changing earth surface conditions seem to have induced new responses of the fluvial geosystem to climate characteristics.

\section{Acknowledgments}

This research project was supported by the 'Action intégrée de coopération franco-marocaine' AI MA 01/01 ('Érosion des sols et sédimentation dans les milieux aquatiques continentaux') between the Science and Technology Faculties of Tours (France) and Fès (Morocco). We thank the French and Moroccan authorities for their help. We thank Elisabeth Yates for her assistance in translating this text and two anonymous reviewers for their constructive comments.

\section{References}

[1] J.-L. Ballais, Alluvial Holocene terraces in eastern Maghreb: climate and anthropogenic controls, in: J. Lewin, M.G. Macklin, J. Woodward (Eds.), Mediterranean Quaternary River Environments, Balkema, 1995, chap. 17, pp. 183-194. 
[2] A. Ballouche, Facteurs climatiques versus facteurs anthropiques : leurs parts respectives dans l'histoire des végétations des montagnes du Maghreb, Moselle, Metz, XXV, 2000, pp. 241-248.

[3] A. Ballouche and P. Marinval, Données palynologiques et carpologiques sur la domestication des plantes et l'agriculture dans le Néolithique ancien du Maroc septentrional (site de Kaf Taht El-Ghar), Rev. Archeometrie 27 (2003), pp. 49-54.

[4] A.Ballouche, D. Lefrèvre, C. Carruesco, J.-P. Raynal, J.-P. Texier, Holocene environments of coastal and continental Morocco, Proc. Symp. on Climatic Fluctuations during the Quaternary in the western Mediterranean Regions, F. Lopez Vera, Madrid, 1986, pp. 517-531.

[5] J.-J. Barathon, Bassins et littoraux du Rif oriental (Maroc). Évolution morphoclimatique et tectonique depuis le Néogène supérieur. Études méditerranéennes, ${ }^{\circ} 13$, C.I.E.M., Poitiers, 1989 (531 p).

[6] J.-J. Barathon, H. El Abassi, C. Lechevallier, F. Malek and M.C. Jolly-Saad, Mise au point sur les formations holocènes dans le Rif oriental (Maroc), Géomorphologie : relief, processus, environnement 4 (2000), pp. 221-238.

[7] H. Brückner, Man's impact on the evolution of the physical environment in the Mediterranean region in historical times, GeoJournal 13 (1) (1986), pp. 7-17.

[8] A. Brun, Microflores et paléovégétations en Afrique du Nord depuis 30000 ans, Bull. Soc. geol. France 8 (1989), pp. 25-33.

[9] A. Calvert, M. Barazangi, D. Seber, F. Gomez, W. Beauchamp, N. Jabbour, A. Ibenbrahim, A. El Maraoui, M. Demnati, M. Ouzzaba and T. Mourabit, A multidisciplinarity seismological and geophysical study of active tectonics on the northeastern coast of Morocco, Am. Geophys. Un. 87 (46) (1995).

[10] R. Cheddadi, H.F. Lamb, J. Guiot and S. van der Kaars, Holocene climatic change in Morocco: a quantitative reconstruction from pollen data, Clim. Dyn. 14 (1998), pp. 883-890. [11] J. Collina-Girard, L'Atlantide devant le détroit de Gibraltar? Mythe et géologie, C.R. Acad. Sci. Paris, Ser. IIa 333 (2001), pp. 233-240

[12] B.A. Davis, S. Brewer, A.C. Stevenson, J. Guiot and data contributors, The temperature of Europe during the Holocene reconstructed from pollen data, Quat. Sci. Rev. 22 (2003), pp. 1701-1716.

[13] A.P. Debkov, V.I. Moszerhin, Erosion and sediment yield in mountain regions of the world, in: D.E. Walling, T.R. Davies, B. Hasholt (Eds.), Erosion, Debris Flows and Environment in Mountain Regions, Proceedings of the Chengdu Symposium, July 1992, IAHS Pub. No. 209 (1992) 29-36.

[14] N. El Hamouti, H. Lamb, J.C. Fontes and F. Gasse, Changements hydroclimatiques abrupts dans le Moyen Atlas marocain depuis le dernier maximum glaciaire, C. R. Acad. Sci. Paris, Ser. II 313 (1991), pp. 259-265.

[15] D. Faust, C. Zielhofer, R. Baena Escudero and F. Diaz del Olmo, High-resolution fluvial record of the Late Holocene geomorphic change in northern Tunisia: climatic or human impact?, Quat. Sci. Rev. 23 (2004), pp. 1757-1775.

[16] K. Fleming, P. Johnston, D. Zwartz, Y. Yokoyama, K. Lambeck and J. Chappell, Refining the eustatic sea-level curve since the Last Glacial Maximum using far- and intermediate-field sites, Earth Planet Sci. Lett. 163 (1998), pp. 327-342.

[17] S.P. Harrison and G. Digerfeldt, European lakes as palaeohydrological and palaeoclimatic indicators, Quat. Sci. Rev. 12 (1993), pp. 233-248.

[18] H.F. Lamb and S. van der Kaars, Vegetational response to Holocene climatic change: pollen and palaeolimnological data from the Middle Atlas, Morocco, The Holocene 5 (4) (1995), pp. 400-408 
[19] H.F. Lamb, F. Damblon and R.W. Maxted, Human impact on the vegetation of the Middle Atlas, Morocco, during the last 5000 years, J. Biogeogr. 18 (1991), pp. 519-532. [20] H.F. Lamb, U. Eicher and V.R. Switsur, An 18,000-year record of vegetation, lake-level and climatic change from Tigalmamine, Middle Atlas, Morocco, J. Biogeogr. 16 (1989), pp. $65-74$.

[21] D. Lefèvre, Formations continentales pléistocènes et paléoenvironnements sédimentaires dans le bassin de Ksabi (Moyenne Moulouya, Maroc), Bull. Assoc. Fr. Et. Quat. 2 (1989), pp. 101-113.

[22] J. Lewin, The impact of Quaternary tectonic activity on river behaviour, in: J. Lewin, M.G. Macklin, J. Woodward (Eds.), Mediterranean Quaternary River Environments, Balkema, 1995, Chap. 2, pp. 1-25.

[23] M.G. Macklin, J. Lewin, J. Woodward, Quaternary fluvial systems in the Mediterranean basin, in: J. Lewin, M.G. Macklin, J. Woodward (Eds.), Mediterranean Quaternary River Environments, Balkema, 1995, Chap. 1, pp. 1-25.

[24] R.H. Meade, T.R. Yuzik, T.J. Day, Movement and storage of sediment in rivers of the United States and Canada, in: The Geology of North America, Vol. 0-1, Surface Water Hydrology, The Geological Society of America, 1990, Chap. 11, pp. 255-280.

[25] A. Montenat, P.D. Ott d'Estevou, P. Barrier and D. Paturel, Les séismites : essai de typologie génétique, Geochronique 46 (1993), pp. 15-17.

[26] C. Morhange and P.A. Pirazzoli, Mid-Holocene emergence of southern Tunisian coasts, Mar. Geol. 220 (2005), pp. 205-213.

[27] P.A. Pirazzoli, Sea level changes, the last 20,000 years, Wiley (1996).

[28] M. Reille, Contribution pollenanalytique à l'histoire holocène de la végétation du Rif (Maroc septentrional), Suppl. au Bull. Assoc. Fr. Et. Quat. 50 (1977), pp. 53-76.

[29] P.J. Reimer, M.G.L. Baillie, E. Bard, A. Bayliss, J.W. Beck, C. Bertrand, P.G.

Blackwell, C.E. Buck, G.S. Burr, K.B. Cutler, P.E. Damon, R.L. Edwards, R.G. Fairbanks, M. Friedrich, T.P. Guilderson, K.A. Hughen, B. Kromer, F.G. McCormac, S. Manning, C. Cronk Ramsey, R.W. Reimer, S. Remmele, J.R. Southon, M. Stuiver, S. Talamo, F.W. Taylor, J. van der Plicht and C.E. Weyhenmayer, IntCal terrestrial radiocarbon age calibration 0-26 cal kyr BP, Radiocarbon 46 (2004), pp. 1029-1058.

[30] P. Rognon, Signification dynamique et climatique des formations et terrasses fluviatiles en Afrique du Nord et au Proche Orient, Bull. Assoc. Fr. Et. Quat. 1-3 (1984), pp. 161-169. [31] P. Rognon, Late Quaternary climatic reconstruction for the Maghreb (North Africa), Palaeogeogr. Palaeoclimatol. Palaeoecol. 58 (1987), pp. 11-34.

[32] P. Rognon and G. Coudé-Gaussen, Paleoclimates of Northwest Africa $\left(28^{\circ}-35^{\circ} \mathrm{N}\right)$ about 18,000 B.P. based on continental eolian deposits, Quat. Res. 46 (1996), pp. 118-126.

[33] A. Seilacher, Sedimentary structures tentatively attributed to seismic events, Mar. Geol., Amsterdam 55 (1984), pp. 1-12.

[34] M. Stuiver and H. Polach, Discusion reporting of ${ }^{14} \mathrm{C}$ data, Radiocarbon 19 (1977), pp. 355-363.

[35] M. Stuiver and P. Reimer, Extended ${ }^{14} \mathrm{C}$ data base and revised Calib $3.0{ }^{14} \mathrm{C}$ age calibration programme, Radiocarbon 35 (1993), pp. 215-230.

[36] J.-F. Troin, Le Nord-Est du Maroc, Rev. Geogr. Maroc 12 (1967), pp. 5-41.

[37] A. Weisrock, A. Ouammou and A. Ait Hssaine, Érosion et sédimentation dans les oueds du Sud-Ouest marocain à l'Holocène, Physio-Geo 22-23 (1991), pp. 95-100.

[38] A. Weisrock, G. Delibrias, P. Rognon and G. Coudé-Gaussen, Variations climatiques et morphogenèse au Maroc atlantique $\left(30-35^{\circ} \mathrm{N}\right)$ à la limite Pléistocène-Holocène, Bull. Soc.

geol. France 8 (4) (1985), pp. 565-569. 
[39] A. Weisrock, L. Wahl, A. Ouammou and L. Chakir, Systèmes fluviaux du Sud-Ouest marocain et leur évolution depuis le Pléistocène recent, Géomorphologie: relief, processus, environnement 4 (2006), pp. 229-248.

[40] L. Wengler, J.-L. Vernet and P. Michel, Évènements et chronologie de l'Holocène en milieu continental au Maghreb. Les données du Maroc oriental, Quaternaire 5 (3-4) (1994), pp. 119-134.

[41] L. Wengler, A. Weisrock, J.-E. Brochier, J.-P. Brugal, M. Fontugne, F. Magnin, J. Mathieu, N. Mercier, A. Ouammou, J.-L. Reyss, F. Senegas, H. Valladas and L. Wahl, Enregistrement fluviatile et paléoenvironnements au Pléistocène récent sur la bordure atlantique de l'Anti-Atlas (Oued Assaka, S-O marocain), Quaternaire 13 (3-4) (2002), pp. 179-192.

[42] H. Zarki, J.-J. Macaire, C. Beck and P. De Luca, Morpho-sedimentary evolution of the lower Moulouya (north-eastern Morocco) during Middle and Upper Holocene. Seismicity and neotectonic effects, Geodin. Acta 17 (3) (2004), pp. 205-217 


\section{Figures and Tables}

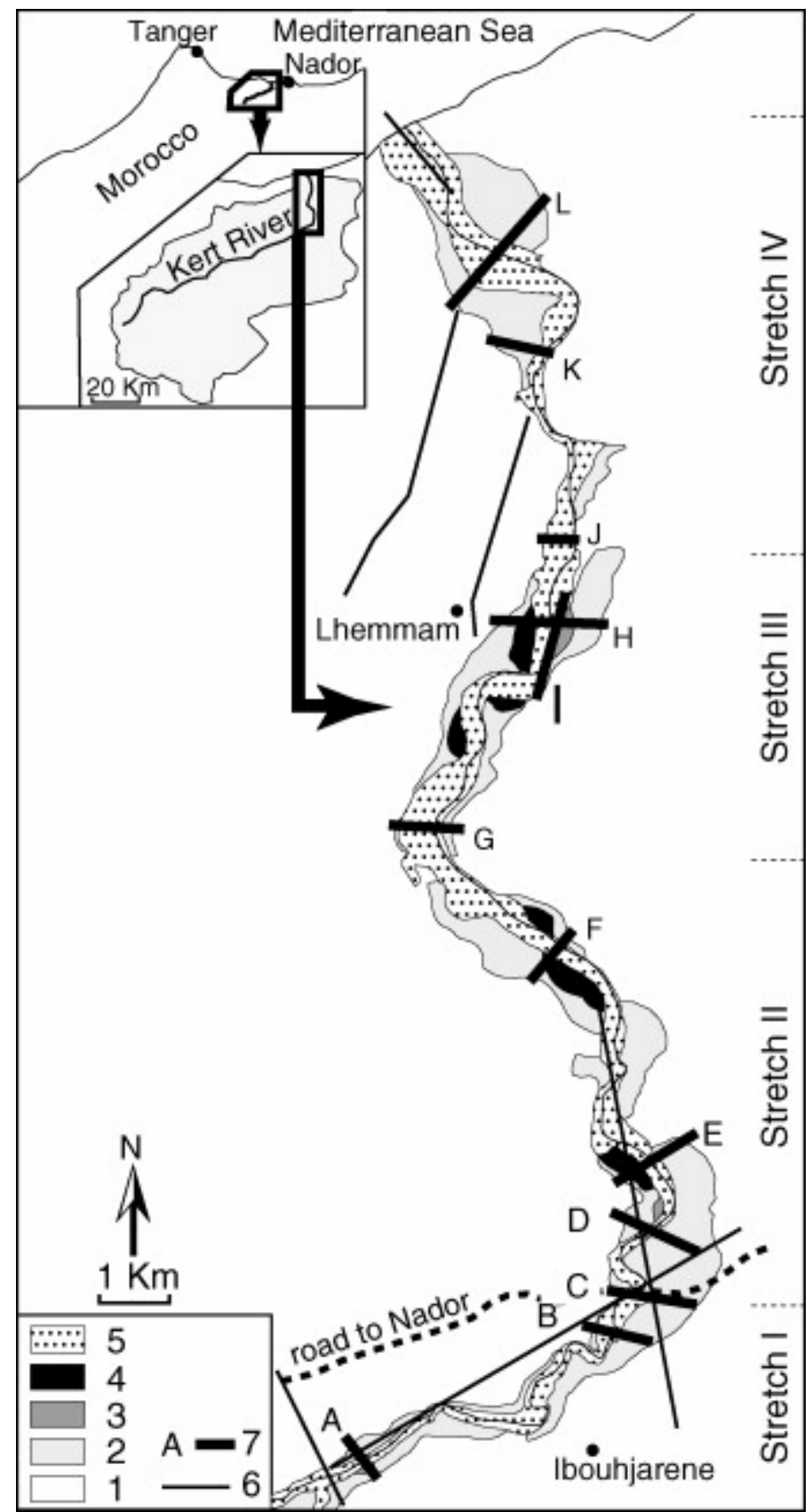

Fig. 1. Lower Kert River valley: location, geological and morphological data: (1) basement; (2) T1 alluvial terrace (Late Pleistocene and Holocene); (3) T2 alluvial terrace (Upper Holocene); (4) T3 alluvial terrace (Upper Holocene); (5) present alluvium; (6) faults (according to [5]); (7) sections of Fig. 2.La basse vallée de l'oued Kert : localisation, données géologiques et morphologiques. (1) substrat ; (2) terrasse alluviale T1 (Pléistocène récent et Holocène) ; (3) terrasse alluviale T2 (Holocène supérieur) ; (4) terrasse alluviale T3 (Holocène supérieur) ; (5) alluvions actuelles ; (6) failles (d'après [5]) ; (7) coupes de la Fig. 2 . 

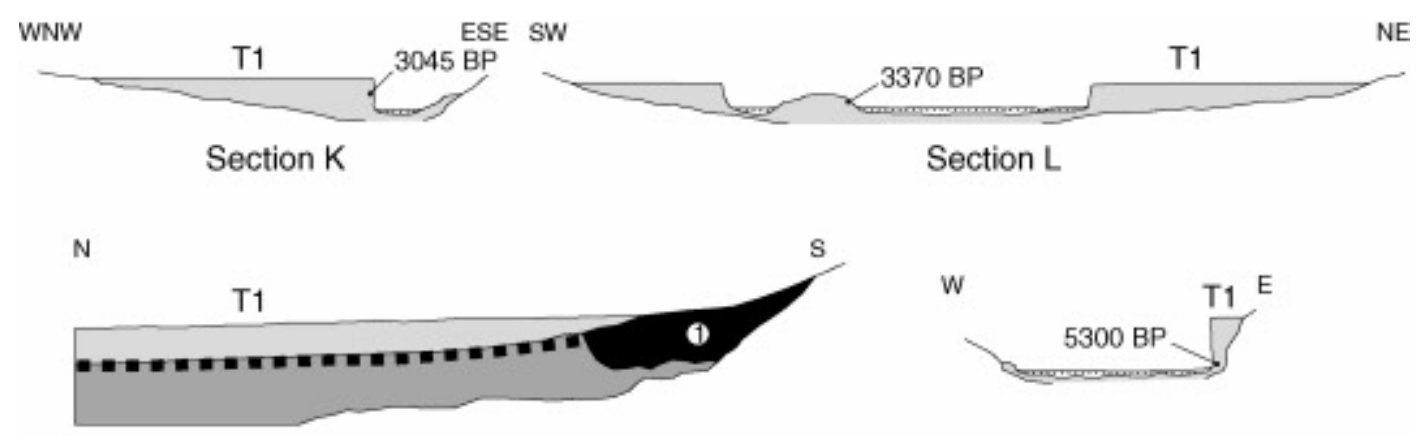

Section I

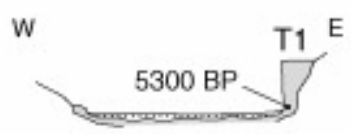

Section J

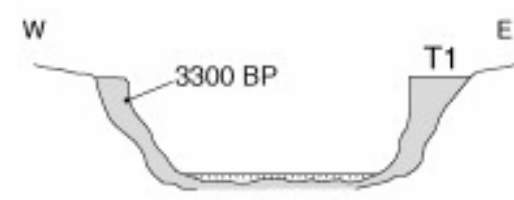

Section G

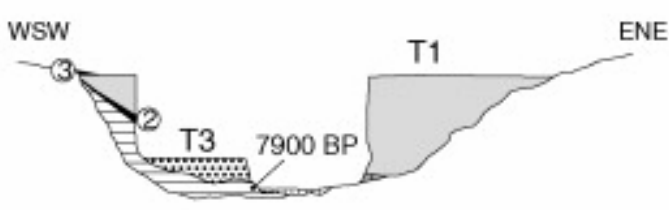

Section $\mathrm{E}$

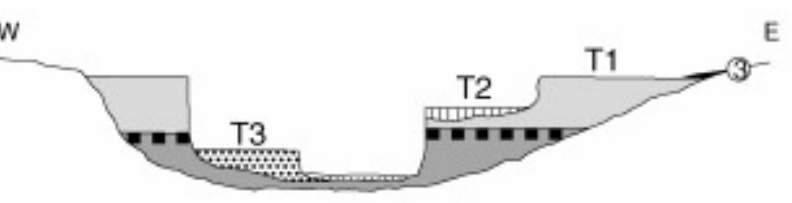

Section $\mathrm{H}$

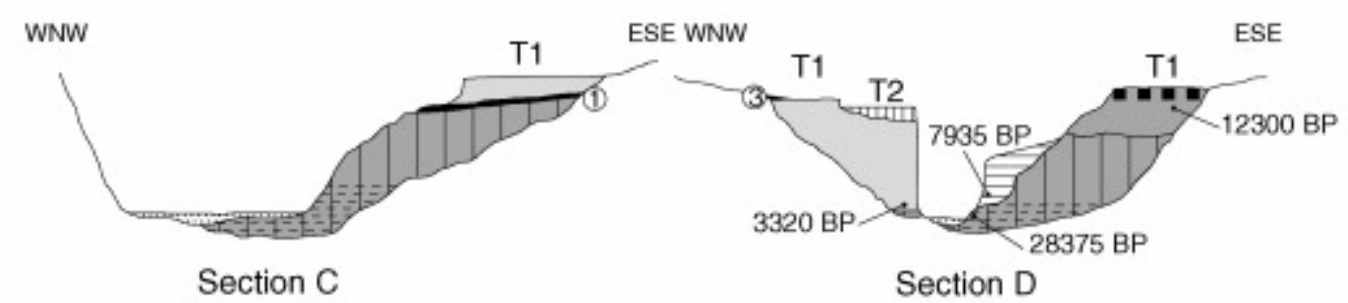

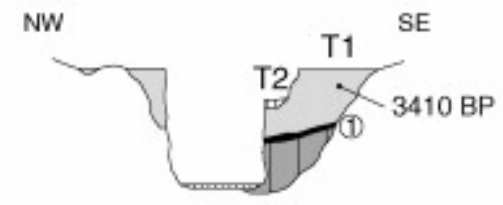

Section A
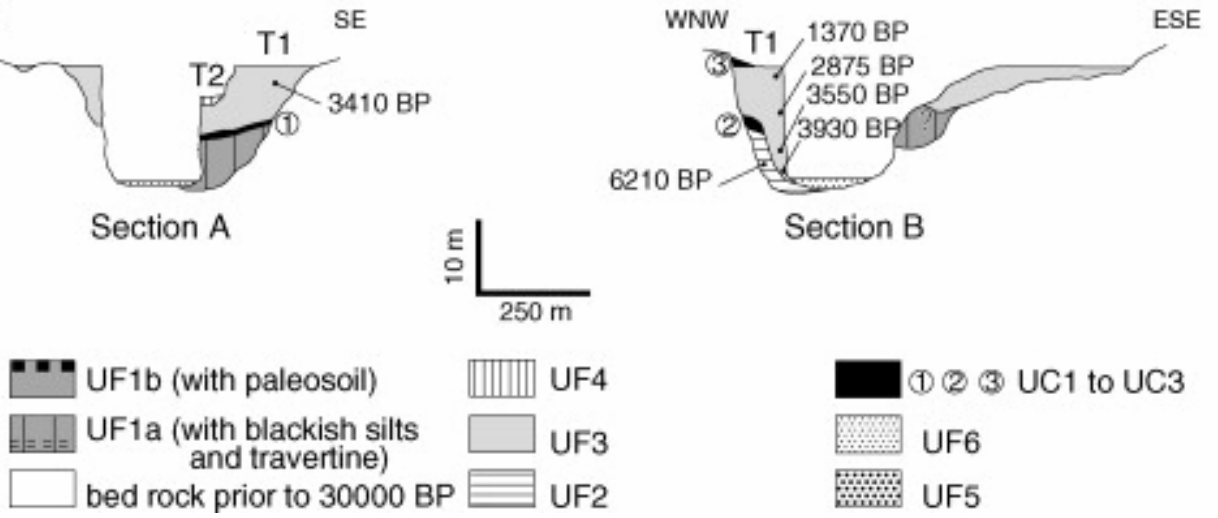

Section $\mathrm{F}$

Section B

Fig. 2. Distribution of lithological units in A to L cross sections (location of sections, see Fig. 1). UF1 to UF6: alluvial units; UC1 to UC3: colluvial units; T1 to T3: alluvial terraces; 3410 BP: age in ${ }^{14} \mathrm{C}$ a BP.Distribution des unités lithologiques dans les coupes transversales $A$ à $L$ (localisation des coupes, voir Fig. 1). UF1 à UF6 : unités alluviales ; UC1 à UC3 : unités colluviales ; $T 1$ à T3 terrasses alluviales ; $3410 \mathrm{BP}$ : âge en années ${ }^{14} \mathrm{C} \mathrm{BP}$. 


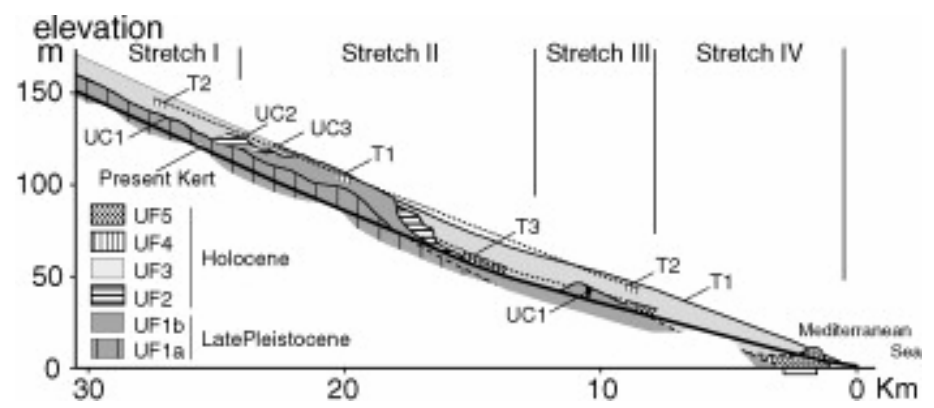

Fig. 3. Upstream-downstream distribution of lithological units. UF1 to UF5: alluvial units; UC1 to UC3: colluvial units; T1 to T3: alluvial terraces.Distribution longitudinale des unités lithologiques. UF1 à UF5 : unités alluviales ; UC1 à UC3 : unités colluviales ; T1 à T3 : terrasses alluviales.

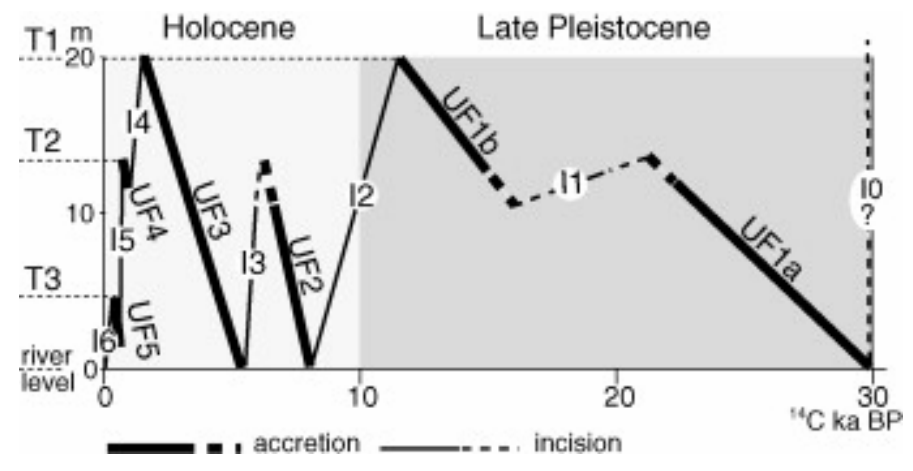

Fig. 4. Pattern of incision and sedimentary accretion stages in valley stretches I and II. I1 to I6: incision; UF1 to UF6: accretion; T1 to T3: alluvial terraces.Schéma de l'enchaînement des phases d'incision et d'accrétion sédimentaire dans les secteurs I et II. I1 à I6 : incision ; UF1 à UF6 : accrétion ; T1 à T3 : terrasses alluviales. 
Table 1. : ${ }^{14} \mathrm{C}$ data. (1) Calibration according to [29], [34] and [35].

Dates ${ }^{14}$ C. (1) Calibration d'après [29], [34] and [35]

\begin{tabular}{|c|c|c|c|c|c|c|}
\hline Unit & Section & Material & Reference & ${ }^{14} \mathrm{C}$-age BP & $\begin{array}{l}\delta 13 C \\
(\%)\end{array}$ & $\begin{array}{l}2 \sigma \text { calibrated }{ }^{14} \mathrm{C} \text {-age } \mathrm{BP} \\
\text { (1) }\end{array}$ \\
\hline \multirow[t]{11}{*}{ UF3 } & A & charcoal & Gif-12086 & $3410 \pm 55$ & -23.01 & $3486-3831$ \\
\hline & B & charcoal & Gif-12082 & $1370 \pm 40$ & -22.58 & $1183-1351$ \\
\hline & B & charcoal & Gif-12083 & $2875 \pm 65$ & -22.48 & $2845-3216$ \\
\hline & B & charcoal & Gif-11958 & $3550 \pm 40$ & -23.12 & $3723-3951$ \\
\hline & B & charcoal & Gif-12085 & $3930 \pm 60$ & -21.66 & $4158-4524$ \\
\hline & $\mathrm{D}$ & charcoal & Gif-11755 & $3320 \pm 55$ & -25.03 & $3408-3689$ \\
\hline & $\mathrm{F}$ & charcoal & Gif-11960 & $3670 \pm 65$ & -22.38 & $3885-4228$ \\
\hline & G & charcoal & Gif-11952 & $3300 \pm 50$ & -20.24 & $3472-3806$ \\
\hline & $\mathrm{J}$ & wood & Gif-11954 & $5285 \pm 45$ & -25.94 & $5933-6175$ \\
\hline & $\mathrm{K}$ & charcoal & Gif-12087 & $3045 \pm 80$ & -24.06 & $3001-3440$ \\
\hline & $\mathrm{L}$ & charcoal & Ly-1197 & $3370 \pm 55$ & & $3465-3819$ \\
\hline \multirow[t]{3}{*}{ UF2 } & B & charcoal & Gif-12088 & $6220 \pm 70$ & -24.44 & $6941-7274$ \\
\hline & $\mathrm{D}$ & charcoal & Gif-11753 & $7935 \pm 45$ & -23.30 & $8611-8989$ \\
\hline & $\mathrm{E}$ & wood & Gif-12084 & $7900 \pm 75$ & -24.96 & 8559-8992 \\
\hline \multirow[t]{2}{*}{ UF1 } & $\mathrm{D}$ & charcoal & Gif-12089 & $12300 \pm 155$ & -24.6 & $13848-14900$ \\
\hline & $\mathrm{D}$ & wood & Gif-11754 & $28375 \pm 450$ & -27.57 & \#30000 \\
\hline
\end{tabular}

